\title{
Multidimensional Examination of Postgraduate Education Theses Related to Problem Behavior in Turkey
}

DOI: $10.26466 /$ opus.841553

Bașak Bağlama * - Cansu Ömer **

* Assistant Professor, Atatürk Faculty of Education, Department of Special Education, Near East University, North Cyprus, Mersin 10 Turkey.

E-Mail: basak.baglama@neu.edu.tr

ORCID: $\underline{0000-0001-7982-8852}$

** Master student, Atatürk Faculty of Education, Department of Special Education, Near East

University, North Cyprus, Mersin 10 Turkey

E-Mail cansuomer97@gmail.com

ORCID: $\underline{0000-0003-1928-5889}$

\begin{abstract}
Aim of this study is to examine current research trends in postgraduate theses related with problem behavior in Turkey. Document analysis as one of the qualitative research methods was used in the study. The study included 60 open-access postgraduate theses obtained from the thesis archive of Higher Education Council (YOK) of Turkey between 2015-2019. Theses included in the research were analyzed using thesis analysis form prepared by the researchers. In the prepared form, theses were examined according to year, level of thesis, university, institute, department, title of thesis supervisor, research model, participant and number of participants, data collection tool and data analysis method. According to the results of the study, it was determined that the most theses on problem behaviors were written in 2018 in the Institute of Educational Sciences and Special Education departments. In addition, it was observed that the number of master theses is higher and the relational survey model and scales are used the most in research. The results obtained within the framework of the investigation were interpreted with percentage and frequency tables and recommendations were presented for future research.
\end{abstract}

Keywords: Problem behavior, special education, postgraduate education, thesis. 
ISSN: 2528-9527

E-ISSN : 2528-9535

YIl Year: 11

Cilt Volume: 17

Sayı Issue:36

Nisan April 2021

Makalenin Gelis Tarihi Received Date. 16/12/2020

Makalenin Kabul Tarihi Accepted Date. 30/04/2021

\title{
Türkiye'de Problem Davranışlar ile İlgili Yapılan Lisansüstü Eğitim Tezlerinin Çok Boyutlu Olarak İncelenmesi
}

\begin{abstract}
$\ddot{O ̈ z}_{\mathrm{z}}$
Bu çalışmanın amacı Türkiye'de problem davranışlar ile ilgili yapılan lisansüstü eğitim tezlerinin çok boyutlu olarak incelenmesidir. Araştırmada nitel araştırma yaklaşımlarından doküman incelemesi yöntemi kullanılmıştır. Araştırmaya Yüksek Öğretim Kurulu'nun (YÖK) tez arşivinden yapılan tarama sonucunda elde edilen ve 1997-2019 yilları arasında erişime açı olan 60 lisansüstü tez dahil edilmiştir. Araştırmaya dahil edilen tezler, araştırmacılar tarafindan önceden hazırlanan tez analizi formu kullanılarak analiz edilmiştir. Hazırlanan formda tezler yazar adı, yayın yıl, hangi üniversite, enstitü, anabilim dalı, şehir, tez düzeyiltürü, danışman ünvanı, araştırma yöntemi, veri toplama aracı, veri analizi yöntemi, katılımcllar ve yöntemine göre incelenmiştir. Araştırmanın sonuçlarına göre, problem davranışlar ile ilgili en fazla tezin 2018 yılında, Ĕ̆itim Bilimleri Enstitüsü ve Özel Eğitim ana bilim dalında yazıldığı görülmüştür. Ayrıca, yüksek lisans tezlerinin sayısının fazla oldŭ̆u, araştırmalarda en fazla ilişkisel tarama modelinin ve ölçeklerin kullanıldığı gözlemlenmiştir. Gerçekleştirilen inceleme çerçevesinde elde edilen bulgular yüzde ve frekans tablolarıla yorumlanmış, ileride yapılacak araştırmalar için önerilerde bulunulmuştur.
\end{abstract}

Anahtar Kelimeler: Problem davranış, özel eğitim, lisansüstü eğitim, tez. 


\section{Introduction}

From the moment the individual is born, he tries to adapt to society throughout his life. He exhibits many behaviors in this adaptation process. These behaviors are called behaviors that are accepted by the society and that are not harmful. At the same time, a person may have unacceptable behavior that harms others and himself. These behaviors are often called problem behaviors (Ceylan and Yikmis, 2017). Problem behaviors are defined as behaviors that harm oneself or others, cause a regression in the social relations and interaction with the social environment, prevent the individual from acquiring knowledge and skills that support all development areas, and do not comply with the general behaviors of the social environment in which he is present (Kanlikilicer, 2005; Slaff 2017).

It is difficult to categorize problem behaviors as women, men, children, adults, adolescents, elderly, young people, or individuals with disabilities or normally developing individuals; because this behavior pattern is a situation that can occur for every individual who has adaptation difficulties. There are many reasons for the emergence of behaviors defined as inappropriate by the society during this adaptation process. American Psychological Association (2013) defines problem behaviors as the violation of social norms and behaviors that are repeatedly exhibited by the fundamental rights of others. De Los Reyes and Kazdin (2009) defined problem behaviors as non-accepted behaviors or non-social behaviors instead of behaviors accepted as normal. The non-social dimension of a behavior is generally categorized on the basis of some features such as the continuity of the behavior, its intensity, its frequency, whether it is a part of a situation that is too contrary to social norms, and whether the judgment of adults around the individual in childhood causes significant harm to the child. The negative behaviors exhibited in a study can be defined as problem behaviors aimed at attracting attention, harmful and not accepted in the social environment (Kanlikilicer, 2005; Estabillo, Matson and Cervantes, 2018).

The problem behaviors that arise are shaped differently for each individual. In the study of Atici (2014), the changes in students' behavior are related to the differences of individuals, family, social environment, genetic characteristics, technology, environment and friends at school, the socioeconomic structure of the family, and the structure of the classroom in the 
first years of school, the behavior of the teacher, and the education program, and teaching methods.

Problem behaviors, whether diagnosed or not, can affect the individual, his family, the people he / she interacts with, peers, the school environment and the teacher. Therefore, it is important to reduce problem behaviors. Looking at the studies and theories on behavior, it is seen that different aspects of the behavior are mentioned. The child's innate behaviors diversify through their interactions with the environment and the child acquires new behaviors (Akcinar and Baydar, 2018). These acquired behaviors may be behaviors that can be accepted by the environment the child interacts with, as well as behaviors that are not accepted and harm the child, his environment and the individuals he interacts with. It can be said that these and similar behaviors are called problem behaviors.

As in individuals with normal development, there are problem behaviors in individuals who need special education. Although problem behaviors vary from person to person, they have determined classifications. Ozyurek (2008) classified problem behaviors according to some criteria. Behavior problems classified according to criteria are evaluated according to the behavior outside the socially acceptable level. Compliance according to the criteria varies according to the quantity of the behavior. The excess and scarcity of behavior is examined in four dimensions. These dimensions are the concealment, severity, frequency, and duration of behavior. Conformity according to other criteria is classified by sub-steps of inappropriate stimulus control. Inappropriate stimulus control is situations seen depending on the context and environment in which the behavior occurs. When the consequences of the behavior are not properly regulated (namely when reinforcement is used carelessly), problematic behavior falls under inappropriate stimulus control (Sheffield and Waller, 2010).

Erbas (2005) collected the functions of problem behaviors under two main headings. These are acquisition and getaway / avoidance behaviors. An example of the acquisition function is obtaining socially motivated (internal) stimuli, gaining pleasure from behaviors such as swinging, finger flicking. Another is stated as obtaining socially motivated stimulus, interest, and activity. The second main topic is the escape / avoidance function. First of all, they are situations such as escaping / avoiding socially motivated (internal) stimuli, pain, and hunger. These include escaping / avoiding so- 
cially motivated stimuli; escaping / avoiding of interest, and finally escaping / avoiding from object or activity.

Gulboy, Yucesoy-Ozkan and Akay (2017) stated that individuals with autism spectrum disorder have problem behaviors. They stated that problem behaviors are repetitive and regenerative, self-harming, containing aggression and anger, unusual eating and obsessive behaviors. They stated that these problem behaviors lead to separation from general education environments, excessive commitment to routines and social interaction problems in individuals. Another problem behavior that can be encountered in normally developing and autistic children, at all age groups and all societies is malnutrition. It is usually a condition that can be caused by psychological and developmental reasons. Feeding disorders are eating behavior disorders that cause medical, social and psychological problems and negatively affect the quality of life (Oyekcin and Sahin, 2011).

Many studies have been put forward to intervene in problem behaviors that occur in individuals who need special education. Alpdogan (2018) investigated the effectiveness of functional communication teaching in reducing problem behaviors in children with autism spectrum disorder. By determining the functions of problem behaviors such as throwing, hitting, biting the resulting items, functional communication skills that can be applied instead of these behaviors have been gained to children. In this study, it was concluded that the function of the problem behaviors exhibited by children is to obtain objects and escape from a difficult task, and that when appropriate communicative skills are acquired to fulfill the function of these problem behaviors, the problem behaviors in children decrease. Atici (2014) explained in his study that educational efforts should yield this result and that more than one variable should be controlled for a long time in order to raise individuals who can exhibit desired behaviors. In addition, he explained that problem behaviors can be reduced when factors such as family, environment, teacher, school, educational environment, educational preparations, increasing the desired behavior and reducing the unwanted are determined.

In another study by Alabay, Guder and Guner (2018), it was determined that crying, tantrums, yelling, stubbornness were the most common behavioral problems teachers encounter in the classroom. It has been determined that problem behaviors negatively affect the education process and create 
problems. It was stated that teachers frequently apply methods such as "making eye contact", "ignoring", "reward-punishment" regarding problem behaviors, they do not show and teach the right behavior to children and they act more spontaneously. According to the results of Acar, Gunes and Kaya (2017) study, it was determined that children's developmental characteristics and negative behaviors change as they get older. With advancing age, children have behaviors such as maternal child addiction, temper tantrums, communication problems, crankiness and restlessness, inability to share, inability to make friends It was emphasized that in order to turn these negative behaviors into positive, parents should be able to listen to their children in order to improve their communication and social skills, and to observe their children's friends and how they communicate with them. As a result, a positive increase in listening and communication skills was observed in children.

In a study conducted by Yetkin and Aksoy (2019), when the attitudes of parents of children with autism according to their demographic characteristics and the differentiation in social skills and problem behaviors of children were examined, it has been revealed that the attitudes of parents who are younger, have primary school level, unemployed and low income level differ in terms of being overprotective. On the other hand, it has been determined that the attitudes of parents who are older, have high school or higher education, are working or have stopped working and have a high income level adopt a permissive attitude. When the third question of the study, parental attitudes and differentiation in social skills and problem behaviors of children was examined, it has been determined that parents whose children have sleep problems and receive more supportive education adopt authoritarian attitude. It has been stated that all these affect the problem behaviors seen in children.

Considering that problem behaviors are a situation that needs to be intervened in educational environments, the analysis of the postgraduate theses on this subject seems meaningful in terms of describing the point reached. In this respect, it is thought that the examination of postgraduate theses on problem behaviors can provide information about the depth and prevalence of this subject and reveal a general view of the area studied. As a matter of fact, in the literature review, it was seen that there was no study analyzing the postgraduate theses on problem behaviors in Turkey. It is 
believed that the research will shed light on practices and, in particular, researchers in this field. Therefore, "What is the distribution of the graduate thesis on the subject of behavior problems in Turkey" constitutes the problem statement of this research. Regarding the related problem statement of the research, sub-problems of the study included revealing the distribution of postgraduate theses on problem behaviors in Turkey according to year, university, institute, department, thesis level, title of the supervisor, language, city, participants, data collection tool and data analysis methods.

\section{Method}

\section{Research Model}

Document analysis as one of the qualitative research methods was used in the study. Simsek and Yildirim (2011) explained the method of document analysis as it includes the analysis of written materials containing information about the phenomena and phenomena aimed to be investigated. Document analysis has traditionally been a model used by historians, anthropologists and linguists, sociologists and psychologists. The document review process includes some stages, including editing data, reviewing data, coding, dividing it into themes and categories, determining how to present it, and interpreting the findings (Creswell, 2013).

\section{Target Population and Sample}

The target population of the research consists of 66 graduate theses on problem behavior conducted in Turkey, which have been completed by 2019 . Due to the limitation that all theses are not open to the reader, all theses could not be reached. The number of postgraduate theses that are not accessible in the research is 6 . For this reason, the sample of the study consists of 60 graduate theses conducted between 1997 to 2019 on problem behaviors that are open to access. The first study obtained in the review belongs to 1997 and is the first research open to access.

\section{Data Collection Process}

The data obtained in this research were collected by using the thesis archive link on the National Thesis Center website (https://tez.yok.gov.tr/UlusalTezMerkezi/ ) in March 2020. For this, the 
"Simple Survey" option on the national thesis center page on the official website of the Higher Education Institution was selected and the words "problem behavior" were written as the key word, and then the permission status was selected as "all". The theses were examined and the number of accessible theses was obtained as 60 in 66 graduate theses. The dates of the theses found include the period from 1997, the year of the first study in the field, to the last month of 2019, when the document analysis was carried out. In the study, data was obtained from theses about problem behavior found in Turkey by document review method and analysis of various characteristics of these data was carried out in SPSS 22.0 program (Statistical Package for the Social Sciences).

\section{Data Collection Tools}

In this study, graduate education theses were evaluated by the researchers with a 13-item thesis analysis form. The items in this form reveals the name of the author, the year of publication, the university where it was prepared, the institute where it was prepared, the department where it was prepared, the level and type of thesis, the title of the thesis, the research method, the data collection tool, the data analysis method, the participants, the subject (what was studied).

\section{Data Analysis}

In the research, various characteristics of the data obtained by document review method from theses on problem behavior prepared in Turkey were analyzed in SPSS program. Distribution of theses by year, distribution of theses by universities, distribution of theses by institutes, distribution of theses by departments, distribution of theses by thesis level, distribution of theses by consultant titles, distribution of theses by literary language, distribution of theses by cities where they are prepared, distribution of theses by participants, distribution of theses according to research methods, distribution of theses according to data collection tools, distribution of theses according to data analysis methods are presented in graphs and tables. These figures and tables presented were systematically interpreted in accordance with the general purpose of the research. 
In order to ensure the reliability of the study, theses examined within the scope of the research were shared by the researchers. The classification was completed in four stages by the researchers. In the first stage, each researcher entered the data of the articles examined and in the second stage, the accuracy of the entered data was checked by another researcher by reexamining the theses. In the third stage, the surveys were checked again in groups of two. In the last stage, the data were checked again by the researchers and the deficiencies were corrected. In this way, the internal validity and reliability of the study was tried to be ensured.

\section{Results}

In this section, the results obtained from the analysis of the data are expressed in terms of percentage $(\%)$ and frequency $(\mathrm{f})$, grouped and tabulated according to the relevant categories and comments based on the analysis results are made.

\section{Distribution of Theses According to Year}

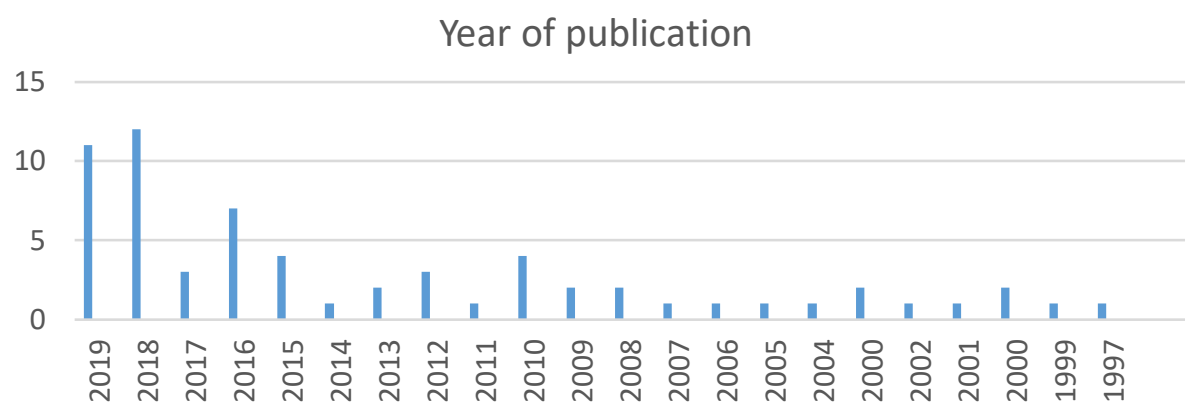

Figure 1. Distribution of postgraduate theses on problem behaviors according to year

When the distribution of theses by years is examined, it is seen that 11 of the theses were written in 2019, 12 of them were written in 2018, 3 of the theses were written in 2017, 7 of the theses were written in 2016, 3 of the theses were written in 2015, 1 of the theses was written in 2014, 2 of the theses were written in 2013, 3 of the theses were written in 2012, 1 of the theses were written in 2011, 4 of them were written in 2010, 2 of the theses were written in 2009, 2 of the theses were written in 2008, 1 of the theses was writ- 
ten in 2007, 1 of the theses was written in 2006, 1 of the theses was written in 2005, 1 of the theses was written in 2004, 2 of the theses were written in 2000,1 of the theses was written in 1999, and 1 of the theses was written in 1997.

\section{Distribution of Theses According to University}

Table 1. Distribution of postgraduate theses on problem behaviors according to university

\begin{tabular}{lll}
\hline University & f & \% \\
\hline Anadolu University & 8 & 13.3 \\
Marmara University & 7 & 11.7 \\
Gazi University & 7 & 11.7 \\
Ankara university & 6 & 10.0 \\
Cukurova University & 4 & 6.7 \\
\hline
\end{tabular}

When the distribution of theses by universities is examined, it is seen that $8(13.3 \%)$ of the theses were written at Anadolu University, $7(11.7 \%)$ of the theses were written at Marmara University, $7(11.7 \%)$ of the theses were written at Gazi University, $6(10.0 \%)$ of the theses were written at Ankara University, and 4 (6.7\%) of the theses were written in Çukurova University.

\section{Distribution of Theses According to Institute}

Table 2. Distribution of postgraduate theses on problem behaviors according to institute

\begin{tabular}{lll}
\hline Institute & f & \% \\
\hline Institute of Educational Sciences & 33 & 55.0 \\
Social Sciences Institute & 22 & 36.7 \\
Health Sciences Institute & 5 & 8.3 \\
Total & $\mathbf{6 0}$ & $\mathbf{1 0 0}$ \\
\hline
\end{tabular}

When the distribution of theses according to institutes is examined, it is determined that $33(55.0 \%)$ of the theses were written in the Institute of Educational Sciences, $22(36.7 \%)$ of the theses were written in the Social Sciences Institute, $5(8.3 \%)$ of the theses were written in the Institute of Health Sciences.

\section{Distribution of Theses According to Department}

Table 3. Distribution of postgraduate theses on problem behaviors according to institute

\begin{tabular}{lll}
\hline Department & f & $\%$ \\
\hline Special education & 18 & 30.0 \\
General Education & 15 & 25.0 \\
Primary education & 10 & 16.7 \\
\hline
\end{tabular}




\begin{tabular}{lll}
\hline Psychology & 8 & 13.3 \\
Child Development & 4 & 6.7 \\
Pre-school Education & 2 & 3.3 \\
Psychological Services in Education & 2 & 3.3 \\
Applied Behavior Analysis & 1 & 1.7 \\
Total & $\mathbf{6 0}$ & $\mathbf{1 0 0}$ \\
\hline
\end{tabular}

When the distribution of theses according to departments is examined, it is seen that 18 of the theses $(30.0 \%)$ were written in special education, 15 $(25.0 \%)$ of the theses were written in basic education, $10(16.7 \%)$ of the theses were written in primary education, $8(13.3 \%)$ of the theses were written in psychology, 4 of the theses $(6.7 \%)$ were written in child development, 2 of the theses (3.3\%) were written in pre-school, 2 of the theses (3.3\%) were written in psychological services in education, and $1(1.7 \%)$ of the theses was written in applied behavior analysis.

\section{Distribution of Theses According to Thesis Level}

Table 4. Distribution of postgraduate theses on problem behaviors according to thesis level

\begin{tabular}{lll}
\hline Thesis level & $\mathbf{f}$ & $\mathbf{\%}$ \\
\hline Master thesis & 49 & 81.7 \\
Doctorate thesis & 11 & 18.3 \\
Total & $\mathbf{6 0}$ & $\mathbf{1 0 0}$ \\
\hline
\end{tabular}

When the distribution of theses according to thesis levels is examined, it is seen that $49(81.7 \%)$ of the theses were written as master theses and 11 $(18.3 \%)$ were written as doctorate thesis.

\section{Distribution of Theses According to the Title of Supervisor}

Table 5. Distribution of postgraduate theses on problem behaviors according to title of supervisor

\begin{tabular}{lll}
\hline Title of the Advisor & $\mathbf{f}$ & $\mathbf{\%}$ \\
\hline Professor & 20 & 33.3 \\
Associate Professor & 19 & 31.7 \\
Assistant Professor & 20 & 33.3 \\
Doctor & 1 & 1.7 \\
Total & $\mathbf{6 0}$ & $\mathbf{1 0 0}$ \\
\hline
\end{tabular}

When the distribution of theses according to the title of advisor is examined, it is seen that 20 of the theses (33.3\%) was prepared with a consultant with the title of Professor, 19 of the theses (31.7\%) was prepared with a consultant with the title of Associate Professor, 20 of the theses (33.3\%) was 
prepared with a consultant with the title of Assistant Professor, and 1 of the theses $(1.7 \%)$ was prepared with a consultant with the title of Doctor.

\section{Distribution of Theses According to Language}

Table 6. Distribution of postgraduate theses on problem behaviors according to language

\begin{tabular}{lll}
\hline Written Language & f & \% \\
\hline Turkish & 55 & 91.7 \\
English & 5 & 8.3 \\
Total & $\mathbf{6 0}$ & $\mathbf{1 0 0}$ \\
\hline
\end{tabular}

When the distribution of theses according to the writing language is examined, it is seen that $55(91.7 \%)$ of them are written in Turkish and $5(8.3 \%)$ of them are written in English.

\section{Distribution of the Theses According to the Cities in which They Were} Conducted

\begin{tabular}{lll}
\multicolumn{2}{l}{ Table 7. Distribution of postgraduate theses on problem } & behaviors according to city \\
\hline Name of the city & f & $\%$ \\
\hline Ankara & 18 & 30.0 \\
Istanbul & 15 & 25.0 \\
Eskisehir & 8 & 13.3 \\
Adana & 4 & 6.7 \\
Total & $\mathbf{6 0}$ & $\mathbf{1 0 0}$ \\
\hline
\end{tabular}

When the distribution of the theses according to the cities where they were prepared is examined, it is determined that 18 of the theses $(30.0 \%)$ were written in Ankara, 15 (25.0\%) of the theses were written in Istanbul, 8 $(13.3 \%)$ of the theses were written in Eskisehir, 4 of the theses $(6.7 \%)$ were written in in Adana.

\section{Distribution of Theses According to Participants}

Table 8. Distribution of postgraduate theses on problem behaviors according to partici-

\begin{tabular}{lll} 
pants & f & \% \\
\hline Participants & 19 & 31.7 \\
\hline Preschool children & 7 & 11.7 \\
Preschool children and their mothers & 6 & 10.0 \\
Pre-school teachers & 5 & 8.3 \\
Students with intellectual disability & 4 & 6.7 \\
Mothers & 4 & 6.7 \\
Adolescents & 4 & 6.7 \\
Classroom teachers & 3 & 5.0 \\
Individuals with autism & &
\end{tabular}




\begin{tabular}{lll}
\hline Refugee children & 2 & 3.3 \\
Mainstreaming students & 2 & 3.3 \\
Gifted children & 1 & 1.7 \\
Teacher candidates & 1 & 1.7 \\
Children with hearing impairment & 1 & 1.7 \\
Fathers & 1 & 1.7 \\
\hline
\end{tabular}

When the distribution of the theses according to the participants is examined, 19 of the participants (31.7\%) are children of pre-school age, 7 of the participants $(11.7 \%)$ are preschool children and their mothers, 6 of the participants $(10.0 \%)$ are preschool teachers, 5 of the participants $(8.3 \%)$ are students with intellectual disability, 4 of the participants (6.7\%) are mothers, 4 of the participants $(6.7 \%)$ are adolescents, 4 of the participants $(6.7 \%)$ are classroom teachers, 3 of the participants (5.0\%) are individuals with autism, 2 of the participants (3.3\%) are refugee children, 2 of the participants (3.3\%) are mainstreaming students, 1 of the participants (1.7\%) is a gifted child, 1 of the participants $(1.7 \%)$ is a teacher candidate, 1 of the participants $(1.7 \%)$ is a hearing impaired children and 1 of the participants $(1.7 \%)$ is a father.

\section{Distribution of Theses According to Research Methods}

Table 9. Distribution of postgraduate theses on problem behaviors according to research method

\begin{tabular}{lll}
\hline Research Method & f & \% \\
\hline Relational Survey Model & 14 & 23.3 \\
Experimental Method & 9 & 15.0 \\
Quantitative Method & 8 & 13.3 \\
Descriptive Research & 7 & 11.7 \\
Qualitative Method & 6 & 10.0 \\
General Survey Pattern & 6 & 10.0 \\
Single Subject Research & 5 & 8.3 \\
Mixed Method & 3 & 5.0 \\
Action Research & 1 & 1.7 \\
Monitoring Research & 1 & 1.7 \\
Total & $\mathbf{6 0}$ & $\mathbf{1 0 0}$ \\
\hline
\end{tabular}

When the distribution of theses according to research methods is examined, it is seen that $14(23.3 \%)$ of them are written as Relational Survey Model, $9(15.0 \%)$ of them are written as Experimental Method, 8 (13.3\%) of them are written as Quantitative Method, $7(11.7 \%)$ of them are written as Descriptive Research, 6 (10.0\%) of them are written as Qualitative Method, 6 $(10.0 \%)$ of them are written as General Survey Model, $5(8.3 \%)$ of them are 
written as Single Subject Research, $3(5.0 \%)$ of them are written as Mixed Method, $1(1.7 \%)$ of them are written as Action Research, $1(1.7 \%)$ of them are written as Monitoring Research.

\section{Distribution of Theses According to Data Collection Tools}

Table 10. Distribution of postgraduate theses on problem behaviors according to research method

\begin{tabular}{lll}
\hline Data collection tool & f & \% \\
\hline Scale & 46 & 76.7 \\
Interview form & 6 & 10.0 \\
Criteria Dependent Measure Tool & 5 & 8.3 \\
Scale + Interview Form & 3 & 5.0 \\
Total & $\mathbf{6 0}$ & $\mathbf{1 0 0}$ \\
\hline
\end{tabular}

When the distribution of theses according to data collection tools is examined, it is determined that 46 of them $(76.7 \%)$ use the Scale, $6(10.0 \%)$ of them use the Interview Form, 5 of them $(8.3 \%)$ use the Criterion Dependent Measurement Tool, and 3 of them (5.0\%) use the Scale and Interview Form.

\section{Distribution of Theses According to Data Analysis Methods}

Table 11. Distribution of postgraduate theses on problem behaviors according to research method

\begin{tabular}{lll}
\hline Data Analysis Method & f & $\%$ \\
\hline Statistical Methods & 46 & 76.7 \\
Content Analysis & 6 & 10.0 \\
Graphical Analysis & 5 & 8.3 \\
Scale + Interview Form & 3 & 5.0 \\
Total & 60 & 100 \\
\hline
\end{tabular}

When the distribution of theses according to data analysis methods is examined, it is determined that $46(76.7 \%)$ of them use Statistical Methods, 6 $(10.0 \%)$ of them use Content Analysis, 5 of them (8.3\%) use Graphical Analysis, and 3 of them $(5.0 \%)$ use Scales and Interview Form.

\section{Discussion}

Theses made between 1997-2019 in Turkey in the field of problem behaviors used in this study were collected by using the thesis archive link on the National Thesis Center web page (https://tez.yok.gov.tr/UlusalTezMerkezi/). Theses were evaluated according to the year they were published and their universities, frequently studied subjects, methods, data collection tools and 
analysis, sample characteristics and sizes. Thus, the general tendencies of these theses were tried to be revealed. In the literature reviews conducted in the field, it is seen that the data for 2018 and 2019 periods contain more studies compared to other theses, especially in terms of up-to-datedness. It is noteworthy that there is more interest in special education and problem behaviors recently.

The research was conducted at the Institute of Educational Sciences, Social Sciences and Health Sciences. But it can be said that the large number of studies conducted in Educational Sciences is due to the fact that it is an area that deals with students and children. Five studies in health sciences should not be ignored and it should be taken into consideration that it is an area where different field experts contribute.

Most of the studies have been done in special education, basic education and primary education departments. It is seen that more research has been done on problem behavior in the fields of psychology and child development. In the study of problem behavior in Turkey conducted by Bayraktar (2018), a total of 20 thesis studies were reached, 3 of which were doctoral and 17 of which were master's theses. However, among the theses made in 2019, 49 master's theses and 11 doctoral theses have been reached. According to the study by Coskun, Dundar and Parlak (2014), when the postgraduate theses in the field of special education are examined in terms of supervisor titles, it is stated that the faculty members with the title of Assistant Professor mostly work as advisors in these theses. In this study on problem behaviors, it is observed that there are more advisors with the title of Professor and Doctor.

In this research on problem behaviors, 55 theses written in Turkish and 5 theses written in English are observed. Since there is no document analysis, especially regarding the research, fragmentary data according to universities are not considered scientific research. In this research, the theses about problem behaviors among universities were examined and presented in detail. In the closest study on the subject, it is seen that a more limited number of information is presented according to the research conducted in the literature review numbers of Marmara and Gazi Universities (Altay, 2020). Ozenc and Ozenc (2013) stated that as a result of their research, the total number of theses made in Ankara and Istanbul is higher than the total of other provinces in Anatolia. It is possible to defend the same issue in re- 
search on problem behaviors. The highest number of theses on this subject is in Ankara and Istanbul, followed by Eskisehir and Adana.

Participants vary in relation to the topic addressed. In a study that examined the effect of Berbercan's (2010) group-family training program for reducing problem behaviors on controlling the behaviors of fathers, it was seen that Berbercan worked with 4 fathers. In another study conducted by Sancak (2019), which investigated the effect of the application of group therapy method in the classroom on the social skills and problem behaviors of preschool children, preschool students are considered as participants.

As a result of Erdem's (2011) study, it was stated that $82 \%$ of scientific research conducted in the field of education in Turkey is carried out using quantitative research methods. In this study on problem behaviors, there are 14 studies using the Relational Survey Model, and one study using action and follow-up studies is observed. In the dimension of examining the studies on problem behaviors in a multifaceted way, it is seen that the scale is mostly used in studies. While the scale was used in 49 studies, the least common study samples were those in which the scale and interview form were used. In the study of Sahin, Kana and Varioglu (2013), it is seen that frequency and percentage analysis methods are frequently used in postgraduate thesis studies on Turkish education. It is observed that statistical methods are mostly used in the studies on problem behaviors.

In this study, postgraduate theses on problem behavior in Turkey were examined in accordance with the established criteria and research trends in studies in this field were revealed. Although there has been an increase in studies on the subject in recent years, it is considered that the studies conducted are not sufficient and it is recommended to increase the number of studies to be carried out. By examining the distribution of graduate theses performed on problem behaviors by thesis level, it was found that the number of Master's thesis studies was much higher than the number of doctoral thesis studies.

It is believed that further research at the doctoral level will be important in providing original research and solution proposals on this topic. By examining the distribution of graduate theses related to Problem behaviors according to research models, it is seen that the relational screening model and experimental research method are used more. With the increase in qualitative and quantitative researches, the realization of perceptions and events 
in the natural environment in a realistic and holistic manner will enable the effectiveness and results of the research process to be revealed more effectively.

The distribution of postgraduate theses on problem behaviors according to data collection tools is mostly scales. Other data collection tools such as observation and interview can be given more space, or the use of data collection tools in which quantitative and qualitative research methods are used together can be increased. When the studies are scanned in terms of the department, it is seen that the data on the main science are not analyzed. In the research, it is important to which discipline the data should be explained. For document analysis, examinations are also made on the basis of the department. Additional information is always needed for more efficient information collection.

\section{References}

Acar, D., Kaya, G., and Gunes, G. (2017). Ozel gereksinimli bireyler hakkindaki goruslere iliskin metafor calismasi. Electronic Journal of Social Sciences, 16(62), 935-944. https://doi.org/10.17755/esosder.284397

Akcinar, B., and Baydar, N. (2018). Erken cocuklukta anne davranislarinin dissallastirma davranis problemleri ile iliskisi. Electronic Journal of Social Sciences, 17(66), 454-470. https://doi.org/10.17755/esosder.325593

Alpdogan, C. (2018). Akilci ilac kullanimi ve paydaslarin rolu: Sakarya ili eczacilari uzerine bir inceleme. Unpublished master thesis. Sakarya University, Turkey.

Altay, N. (2020). Turkiye'de sosyal bilgiler egitimi alaninda yazılan makalelerin degerlendirilmesi. Adnan Menderes Universitesi Egitim Fakültesi Egitim Bilimleri Dergisi, 11(1), 22-35.

American Psychiatric Association, (2013). Diagnostic and statistical manual of mental disorders (5th ed.) Washington, DC: Author.

Atici, R. (2014). Kaynastirma ogrencilerinin okul hayatinda karsilastigi zorluklar. Turkish Studies-International Periodical for the Languages, Literature and History of Turkish or Turkic, 9(5), 295-313. http://dx.doi.org/10.7827/TurkishStudies.6936

Bayraktar, A. (2018). Turkiye'de ozel egitim alaninda problem davranislarla ilgili yapilan lisansustu egitim tezlerinin cok boyutlu olarak incelenmesi. Retrieved from https://uoek2018.ogu.edu.tr/Storage/uoek2018/Uploads/200-210.pdf on 10 September 2020. 
Berbercan, F. (2010). Problem davranislarin azaltilmasina yonelik grup aile egitim programi'nin babalarin davranislari kontrol etmek icin gerekli kavram ve islem sureclerini kazanmalarina etkisi. Unpublished master thesis. Gazi Universitesi, Graduate School of Social Sciences, Ankara.

Ceylan, F., and Yikmis, A. (2017). Kaynastirma ogrencilerinin sergiledigi problem davranislara yonelik sinif ogretmenlerinin uyguladiklari onleme ve mudahale stratejileri. Uludag Universitesi Egitim Fakultesi Dergisi, 30(1), 239-264. https://doi.org/10.19171/uefad.323417

Coskun, I., Dudar, S., and Parlak, C. (2014). Turkiye'de ozel egitim alaninda yapilmis lisansustu tezlerin cesitli değiskenler acisindan incelenmesi (2008-2013). Ege Egitim Dergisi, 15(2), 375-396. https://doi.org/10.12984/eed.49993

Creswell, J. (2013). Qualitative enquiry and research design: Choosing among five approaches (3rd ed.). Los Angeles: Sage.

De Los Reyes, A., and Kazdin, A. E. (2009). Identifying evidence-based interventions for children and adolescents using the range of possible changes model: A meta-analytic illustration. Behavior Modification, 33(5), 583-617. https://doi.org/10.1177\%2F0145445509343203

Erbas, D. (2005). Bas makale: Olumlu davranissal destek. Ankara Universitesi Egitim Bilimleri Fakultesi Ozel Egitim Dergisi, 6(1), 1-18. https://doi.org/10.1501/Ozlegt 0000000087

Erdem, D. (2011). Turkiye'de 2005-2006 yillari arasinda yayimlanan egitim bilimleri dergilerindeki makalelerin bazı ozellikler acisindan incelenmesi: Betimsel bir analiz. Egitimde ve Psikolojide Olcme ve Degerlendirme Dergisi, 2(1), 140-147.

Estabillo, J. A., Matson, J. L., and Cervantes, P. E. (2018). Autism symptoms and problem behaviors in children with and without developmental regression. Journal of Developmental and Physical Disabilities, 30(1), 17-26.

Guder, S. Y., Alabay, E., and Guner, E. (2018). Okul oncesi ogretmenlerinin siniflarinda karsilastiklari davranis problemleri ve kullandiklari stratejiler. Elementary Education Online, 17(1), 414-430.

Gulboy, E., Yucesoy-Ozkan, S., and Akay, E. P. M. (2017). Otizmi olan cocuklarin gecisler sirasinda sergileyebilecekleri problem davranislari onlemek uzere kullanilan gecis stratejileri. Adiyaman Universitesi Sosyal Bilimler Enstitu Dergisi, 25, 53-97

Kanlikilicer, P. (2005). Preschool behavior questionnaire: A validity and reliability study. Unpublished master thesis. Graduate School of Educational Sciences, Marmara University, Istanbul, Turkey. 
Oyekcin, D. G., and Sahin, E. M. (2011). Yeme bozukluklarina yaklasim. Turkiye Aile Hekimligi Dergisi, 15(1), 29-35.

Ozenc, E. G., and Ozenc, M. (2013). Turkiye'de ustun yetenekli ogrencilerle ilgili yapilan lisansustu egitim tezlerinin cok boyutlu olarak incelenmesi. Turkiye Sosyal Arastirmalar Dergisi, 171(171), 13-28.

Ozyurek, M. (2008). Problem darranislari degistirme (4th edition). Ankara: Kok Yayincilik.

Sahin, E., Kana, F., and Varisoglu, B. (2013). Turkce egitimi bolumlerinde yapilan lisansustu tezlerin arastirma egilimleri. International Journal of Human Sciences, 10(2), 356-378.

Sancak, S. (2019). Effects of group theraplay on social skills and problem behaviors of preschoolers in classroom environment. Unpublished master thesis. Graduate School of Social Sciences, Middle East Technical University, Ankara, Turkey.

Sheffield, K. I. M., and Waller, R. J. (2010). A review of single-case studies utilizing selfmonitoring interventions to reduce problem classroom behaviors. Beyond Behavior, 19(2), 7-13.

Simsek, H., and Yildirim, A. (2011). Sosyal bilimlerde nitel arastirma yontemleri. Ankara: Seckin Yayincilik.

Slaff, I. (2017). Use the ABCs when managing problem behaviors in autism. Current Psychiatry, 16(11), 54-55.

Yetkin, A. I., and Aksoy, V. (2019). Maternal acceptance-rejection and mother-child interaction in Turkish mothers of children with developmental disabilities. Journal of Developmental and Physical Disabilities, 31(6), 803-817.

\section{Kaynakça Bilgisi / Citation Information}

Bağlama, B. and Ömer, C. (2021). Multidimensional examination of postgraduate education theses related to problem behavior in Turkey. OPUS-International Journal of Society Researches, 17(36), 2383-2401. DOI: 10.26466/opus.841553 